Grażyna Cęcelek* (D) http://orcid.org/0000-0002-2303-7442

Państwowa Uczelnia im. Stefana Batorego

https://doi.org/10.25312/2083-2923.18/2020_05gc

\title{
Środowisko uczenia się jako podstawa funkcjonowania współczesnej szkoły
}

\begin{abstract}
Streszczenie: Dynamika oraz złożoność współczesnego świata to ważne wyzwania dla systemów edukacyjnych przygotowujących młodych ludzi do uczestniczenia w otaczającej rzeczywistości i radzenia sobie w niej oraz do aktywnego współtworzenia przyszłości. Przyspieszony postęp technologiczny i globalna konkurencja to czynniki towarzyszące egzystencji współczesnego człowieka i jednocześnie istotne determinanty ścieżki życiowej zmierzającej do uzyskania odpowiedniego statusu społecznego. Priorytetem staje się więc antycypacja przyszłości oraz kształcenie do zmian zachodzących w każdej dziedzinie społecznego funkcjonowania.

Potrzeby te dezaktualizują tradycyjne formy przekazu edukacyjnego i jednocześnie generują konieczność zastąpienia procesu wychowania adaptacyjnego wychowaniem innowacyjnym oraz antycypacyjnym, nastawionym na proces budowy i rozwijania nowych kompetencji. Ważnym zadaniem współczesnej szkoły jest więc otwarcie się na zmiany oraz poszukiwanie adekwatnych, dostosowanych do nowych potrzeb, wzorców pedagogicznego działania. Formułą nowej koncepcji kształcenia staje się preferowanie procesu uczenia się realizowanego w szkole jako organizacji uczącej się - w oparciu o założenia konstruktywistycznego modelu edukacji, zakładającego uznanie aktywności własnej dziecka za główny mechanizm jego zmian rozwojowych.
\end{abstract}

Słowa kluczowe: szkoła, edukacja, nauczanie, uczenie się, konstruktywistyczny model edukacji, konstruowanie wiedzy

* Grażyna Cęcelek - doktor nauk humanistycznych w zakresie pedagogiki, profesor Państwowej Uczelni im. Stefana Batorego. Autorka i współredaktorka monografii pedagogicznych oraz ponad 100 artykułów naukowych z pogranicza pedagogiki społecznej, opiekuńczo-wychowawczej, resocjalizacyjnej, pedagogiki bezpieczeństwa, a także z obszaru edukacji włączającej, edukacji permanentnej, e-edukacji, pedagogiki medialnej i doradztwa edukacyjno-zawodowego - opublikowanych w polskich i zagranicznych periodykach i monografiach naukowych. 


\section{Wprowadzenie}

We współczesnym, charakteryzującym się ogromną dynamiką zmian i coraz bardziej nieprzewidywalnym świecie, w którym „wczorajsze wypróbowane trasy zmieniają się z dnia na dzień w ślepe zaułki, a tradycyjne, kiedyś niezawodne wzory postępowania, zamiast zapewniać sukces, prowadzą do klęski”" - niezmiernie ważne jest posiadanie umiejętności uczenia się, pozwalających trafnie identyfikować własne potrzeby i możliwości, sprawnie i bezkolizyjnie poruszać się w codzienności oraz racjonalnie korzystać z ogromnych zasobów informacji. Największe szanse na radzenie sobie z życiowymi wyzwaniami oraz na odniesienie sukcesu mają osoby, które potrafią samodzielnie poszerzać wiedzę oraz korzystać z niej w praktyce, wykazując w tych działaniach duże zaangażowanie, wytrwałość, konsekwencję oraz entuzjazm. „To właśnie połączenie pasji, kreatywności i talentu staje się obecnie głównym udziałowcem w budowaniu kapitału intelektualnego"2. Wiedza postrzegana jest zatem jako niezwykle znaczący zasób, a nawet rodzaj kapitału wytwórczego. „Współczesne społeczeństwa określa się w związku z tym mianem społeczeństw wiedzy lub społeczeństw informacyjnych"3.

Zasygnalizowane potrzeby stawiają nowe wyzwania przed instytucją szkoły jako ważnym środowiskiem wychowawczym oraz podstawowym ogniwem edukacji młodego pokolenia, polegające na konieczności otwarcia się na nowe sposoby działania pedagogicznego przygotowującego ucznia „do samodzielnego funkcjonowania w świecie, radzenia sobie z jego złożonością i kreowania nowych, optymalnych dla zmian rzeczywistości rozwiązań" ${ }^{4}$. Wymogi takie determinują potrzebę kreowania edukacji rozwijającej, opartej na aktywności wychowanka i ukierunkowanej na wszechstronne wsparcie podmiotowe rozwoju dziecka. „Formułą nowej koncepcji kształcenia powinna być kreacja edukacji nie tylko na możliwości dnia dzisiejszego, preferująca kształcenie zachowawcze, lecz także na możliwości i potrzeby jutra" ${ }^{5}$, dlatego też antycypacja przyszłości bazująca na „kształceniu do nieustannie zachodzących, dynamicznych zmian” powinna stanowić podstawowy filar przemian edukacji.

Fundamentem takiego podejścia jest konstruktywistyczny model edukacji, ukierunkowany na realizację procesu konstruowania, czyli tworzenia własnej wiedzy

${ }^{1}$ Z. Bauman, 44 listy ze świata płynnej nowoczesności, Wydawnictwo Literackie, Warszawa 2011, s. 152.

${ }^{2}$ J. Nowak, Środowisko uczące-(nie)doceniony obszar edukacji, [w:] K. Kruszko, I. Nowakowska-Buryła (red.), Problemy edukacji wczesnoszkolnej. Perspektywa teoretyczna i rozwiąania praktyczne, Wydawnictwo UMCS, Lublin 2015, s. 64.

3 Z. Kawka, Edukacja szansq na integracje społeczna, [w:] M. Kozłowski (red.), Edukacja jako szansa na integrację społeczna, Wydawnictwo Państwowej Wyższej Szkoły Zawodowej w Skierniewicach, Skierniewice 2010, s. 40.

${ }^{4}$ J. Kordziński, Szkoła uczenia się, Wolters Kluwer, Warszawa 2018, s. 17.

${ }^{5}$ G. Cęcelek, Kompetencje społeczne nauczyciela szkoły uczenia się $i$ wyrównywania szans edukacyjnych, Wydawnictwo Adam Marszałek, Toruń 2020, s. 8. 
przez wychowanków w oparciu o nieustanną konfrontację z otoczeniem oraz wnikliwy dialog wewnętrzny, bowiem „taki sposób tworzenia i przekazywania nowej wiedzy jest $\mathrm{w}$ dobie szumu informacyjnego zdecydowanie bardziej praktyczny od form tradycyjnych"6.

\section{Szkoła jako środowisko kreujące przyszłość wychowanków}

Szkoła stanowi instytucję powołaną do systematycznego kształcenia młodego pokolenia, w związku z czym ponosi obok domu rodzinnego ogromną odpowiedzialność za właściwe przygotowanie młodego człowieka do świadomego obywatelstwa, aktywnego uczestnictwa w życiu społecznym oraz do radzenia sobie z nowymi, nieprzewidywalnymi sytuacjami i problemami. „Środowisko szkolne stanowi podstawowe ogniwo edukacji młodych pokoleń, to dlatego przede wszystkim na nim spoczywa obowiązek rozbudzania aktywności życiowej, kształtowania zaradności społecznej oraz motywowania wychowanków do kreowania własnego, wartościowego stylu życia"7.

Solidna edukacja postrzegana jest w obecnych czasach jako jeden z zasadniczych wyznaczników kariery zawodowej oraz pozycji społecznej. Młodzi ludzie coraz wyraźniej doceniają wartość edukacji jako czynnika wyznaczającego pozycję społeczną jednostki, jej prestiż w środowisku oraz miejsce w życiu. Zauważalny jest wyraźny związek zachodzący pomiędzy wykształceniem obywateli a wzrostem gospodarczym kraju. „Rynek pracy jest jednym z podstawowych odbiorców efektów systemu edukacji. Oferowane przez instytucje edukacyjne ścieżki i możliwości uczenia się mają wpływ na szanse zatrudnienia, możliwości rozpoczęcia aktywności zawodowej czy uzyskiwane wynagrodzenie. Edukacja kształtuje zarówno kompetencje ogólne, jak i pozwala na uzyskanie konkretnych kwalifikacji, w tym zawodowych, poszukiwanych przez pracodawców"8. Dlatego też zdobycie odpowiedniego wykształcenia umożliwiającego uzyskanie odpowiedniego zasobu wiedzy, umiejętności oraz kompetencji społecznych stanowi główny wyznacznik jakości przyszłego społecznego funkcjonowania młodego człowieka.

Należy jednocześnie zauważyć, że dynamizm współczesnej rzeczywistości prowadzi do znacznego zróżnicowania poziomu życia społeczeństwa, do polaryzacji społecznej, generując tym samym nierówny dostęp młodego pokolenia do możliwości oferowanych przez systemy edukacyjne. Konieczne w związku z tym jest podjęcie w obszarze funkcjonowania systemów edukacyjnych - działań mających na celu wyrównywanie szans edukacyjnych dzieci i młodzieży. „Prawo do edukacji jest współcześnie traktowane jako jedno z podstawowych praw społeczno-ekonomicznych

6 Tamże, s. 9.

7 Tamże, s. 21.

${ }^{8}$ M. Federowicz, M. Sitek, Społeczeństwo w drodze do wiedzy. Raport o stanie edukacji 2010, Instytut Badań Edukacyjnych, Warszawa 2011, s. 241. 
gwarantowanych przez państwo. Coraz częściej podkreśla się, że nie chodzi jedynie o umożliwienie coraz większej liczbie osób uzyskania świadectwa lub dyplomu, ale o zdobycie przez nich określonego zasobu wiedzy i umiejętności" ${ }^{\prime}$. Wykształcenie daje bowiem możliwość korzystania z wielu innych praw, otwiera szansę osiągania licznych pożądanych dóbr ${ }^{10}$, stanowiąc jednocześnie zasadniczy warunek zmniejszania różnic społecznych i kształtowania bardziej egalitarnej struktury ${ }^{11}$. To właśnie dlatego „edukację traktuje się jako jeden z podstawowych instrumentów zwiększania szans na rynku pracy i przeciwdziałania zjawisku wykluczenia społecznego"12.

Dlatego też „szczególnym zadaniem współczesnej szkoły jest jej uczestnictwo w kreowaniu wszystkich podstawowych obszarów funkcjonowania młodego człowieka - z uwzględnieniem działań o charakterze wspierającym, kompensacyjnym, nastawionych na zapewnienie możliwości dostępu każdego dziecka do zdobycia odpowiednich kompetencji społecznych oraz umiejętności radzenia sobie w niezwykle złożonym i wymagającym współczesnym świecie"13.

Otwarcie się instytucji szkoły na zmiany postrzegane jest więc jako efektywna realizacja idei rozwoju procesu uczenia się poprzez konstruowanie wiedzy oraz niezwykle ważnego procesu równania szans w dostępie do edukacji wszystkich dzieci bez względu na status społeczny, ekonomiczny czy kulturowy rodziny ich pochodzenia czy też inne trudności, deficyty i specjalne potrzeby edukacyjne. Jednocześnie jest to duża szansa na rozwój w procesie edukacji i wychowania wartościowego dialogu, na wzrost refleksyjności, na poznanie wartości różnorodności, a tym samym na optymalizację procesu budowania jakości życia oraz współpracy i integracji społecznej.

\section{Uczenie się podstawą funkcjonowania współczesnej szkoły}

Szkoła uczenia się to synonim szkoły stanowiącej ważne miejsce osobistego rozwoju wychowanków, przygotowującej ich do życia i podejmowania wyzwań w trudnej do przewidzenia rzeczywistości. W rozumieniu U. Hammerschmidta ${ }^{14}$ pod pojęciem uczącej się szkoły należy rozumieć szkołę, w której obszarze funkcjonowania spełnione są następujące warunki:

- wychowankowie mają zapewnione jak najlepsze warunki do indywidualnego uczenia się,

9 Tamże, s. 199.

10 A. Ochremiak, Nierówności edukacyjne - problem nie tylko pedagogiczny, „Problemy Opiekuńczo-Wychowawcze" 2002, nr 8, s. 3.

11 Z. Kawka, dz. cyt., s. 41.

12 M. Federowicz, M. Sitek, dz. cyt., s. 199.

13 G. Cęcelek, Kompetencje..., dz. cyt., s. 9.

14 U. Hammerschmidt, Ucząca się szkoła? Uczący się nauczyciele! Próba refleksji krytycznej i punkt wyjścia do rekonstrukcji, [w:] G. Mazurkiewicz, Teoria ewolucji. Od rozwoju jednostek do rozwoju wspólnoty, Wydawnictwo Uniwersytetu Jagiellońskiego, Kraków 2015, s. 31. 
- nauczyciele traktują się jako podmioty badające,

- indywidualne doświadczenia uczenia się są otwarcie komunikowane,

- wprowadzone są zasady (samo)refleksji i są one praktykowane,

- racjonalność jest pojmowana jako jedność rozumu, emocjonalności i działania,

- wszyscy zainteresowani pielęgnują we wzajemnych kontaktach klimat szacunku i zaufania.

Przez wiele lat szkoła była miejscem, w którym dominowało nauczanie oparte na transmisyjnym, suchym przekazie wiedzy przez nauczyciela. „W efekcie wytworzyła się praktyka polegająca na tym, że ośrodkiem decydującym o tym, czego, w jakim tempie, jakimi metodami uczono uczniów, był przede wszystkim, a niekiedy wyłącznie, nauczyciel. Nawet w sytuacji, kiedy jakaś część uczniów nie dawała rady i trochę, a z czasem jeszcze bardziej niż trochę, pozostawała w tyle. Również kiedy jakaś część uczniów znała już i potrafiła to, czego uczył nauczyciel, i trochę, a z czasem jeszcze bardziej niż trochę, zaczynała się nudzić. Obok nauczyciela decydującego o procesie nauczania nie mniej ważnym dysponentem wyznaczającym sposób organizacji nauczania był program, który gonił i którego realizacja była głównym wyznacznikiem właściwego nauczania. Ponieważ uczeń miał się uczyć tylko tak, jak był nauczany, musiał się podporządkowywać narzuconemu procesowi. Wszelkie odstępstwa traktowane były jako przejaw buntu, arogancji czy nieposłuszeństwa"15.

Głównym zadaniem współczesnej szkoły jest zapewnienie uczniowi jako dynamicznie rozwijającej się jednostce środowiska, w którym ten rozwój będzie się odbywał w sposób optymalny. Z jednej strony to kwestia zagwarantowania właściwej infrastruktury, wyposażenia pracowni w oprzyrządowanie pozwalające prowadzić badania i eksperymenty, ale także zapewnienie dostępu do internetu czy wykorzystywanie zasobów biblioteki w szkole jako potencjalnego centrum praktycznej nauki zarządzania wiedzą. To również kwestia metod pracy nauczycieli - stosowanie metod włączających, indywidualizacja zadań, wykorzystywanie metod projektowych ${ }^{16}$. „Takie ujęcie procesu kształcenia wpisuje się w nowoczesną wizję szkoły, która powinna być zaprzeczeniem szkoły tradycyjnej i edukacji schematycznej"17.

Tak więc w czasach współczesnych, kiedy wiedza przestała być aksjomatem, a dostęp do informacji stał się praktycznie nieograniczony, uczenia nie utożsamiamy już z nabywaniem wiedzy o świecie, ale z umiejętnym funkcjonowaniem w realiach zmieniającej się rzeczywistości. Następuje w związku z tym wyraźne przesunięcie z uczenia na uczenie się; z tego, czego się uczymy, na rzecz tego, jak się uczymy. W takim ujęciu uczenie się rozumiane jest jako zapis form aktywności, jakie uczeń podejmuje względem siebie i świata, w skład których wchodzą pytania wyznaczające obszar eksploracji, poszukiwań nowych trajektorii poznania, obserwacji i badań prowadzące do

15 J. Kordziński, dz. cyt., s. 78-79.

16 Tamże, s. 79.

${ }^{17}$ K. Borawska-Kalbarczyk, Konstruktywistyczna teoria kształcenia $w$ praktyce edukacyjnej wybrane aspekty, „Kultura i Edukacja” 2012, nr 1(87), s. 136. 
uzyskania odpowiedzi oraz wnioskowania na podstawie wcześniej wyprowadzonych sądów i uogólnień. Procesu uczenia się nie można zadekretować poprzez narzucenie sztywnych ram czasowych i przestrzennych. Nie wpisuje się on również w ograniczony obszar podręcznikowych doświadczeń. Uczymy się wszędzie i ciągle, a przestrzeń praktyk uczniowskich jest rozległa i często wykracza poza mury szkoły, sięgając po zasoby rzeczywistego świata materialnego oraz zapośredniczonego świata wirtualnego $^{18}$. „Wydaje się, że najważniejsze współcześnie staje się to, aby działalność oświatowa - szkolna i pozaszkolna - nie była zorientowana wyłącznie na przystosowanie młodych pokoleń do zastanych warunków, lecz na nauczanie uczenia się, rozwijanie myślenia twórczego i samodzielnego kierowania własnym życiem"19.

Skuteczność takiego procesu uwarunkowana jest w dużym stopniu poziomem zaangażowania jednostki, która wiedziona własną ciekawością i wrażliwością poznawczą poddaje nieustannej konstrukcji, rekonstrukcji i dekonstrukcji dotychczasową wiedzę, umiejętności i zachowania, przystosowując się do nowych warunków i sytuacji, z którymi przyjdzie się zmierzyćc ${ }^{20}$. Niezwykle ważna w tych działaniach jest motywacja, poczucie sprawstwa, wiara we własne możliwości oraz dostrzeganie choćby najmniejszych osiągnięć i postępów zarówno przez podmiot uczący się, jak i przez nauczyciela, który mu w tym procesie towarzyszy i jest jego współtwórcą. Inne ważne elementy stanowiące fundament efektywnego uczenia się to: namysł i refleksja nad własnym myśleniem i działaniem, dzielenie się wiedzą, interpretacja doświadczeń w interakcji z innymi, wartościowy edukacyjny dialog. Dla zaistnienia prawdziwego dialogu niezbędnego dla realizacji procesu uczenia się konieczne jest partnerstwo poznawcze nauczycieli i uczniów, którego podstawą jest dopuszczenie nadawania indywidualnych znaczeń i interpretacji faktom, procesom, zjawiskom i pojęciom na rzecz rezygnacji z kultu jedynej, prawidłowej odpowiedzi.

W szkole opartej na dominowaniu procesu uczenia się nad nauczaniem, tworzącej aktywne, twórcze i wspierające środowisko wychowawcze zmienia się pojęcie procesu przywództwa edukacyjnego, które kładzie coraz większy nacisk na partycypację nauczycieli w kierowaniu szkołą, czyli efektywne włączanie wszystkich nauczycieli i pedagogów oraz całej społeczności szkolnej w decydowanie o przebiegu procesu dydaktyczno-wychowawczego. Bowiem to „od liderów w szkole oczekuje się zdolności do rozpoznawania pojawiających się na styku teorii i praktyki możliwości uczenia się i ich wykorzystywania”21. „Tradycyjny styl kierowania z elementami autorytaryzmu i dominacji pozbawia samodzielności, uzależnia i zwalnia z myślenia

${ }^{18}$ J. Nowak, dz. cyt., s. 65.

19 R. Stępień, Aktualne tendencje rozwoju dydaktyki ogólnej i jej rola w edukacji pedagogicznej, [w:] R. Stępień (red.), Kształcenie pedagogów w szkole wyższej. Teoria i praktyka, Akademia Humanistyczna im. Aleksandra Gieysztora w Pułtusku, Pułtusk 2015, s. 83.

${ }^{20}$ J. Nowak, dz. cyt., s. 65.

${ }^{21}$ J. Madalińska-Michalak, Przywództwo dyrektora szkoły a zmiana i uczenie się nauczycieli we wspólnotach praktyków, „Rocznik Lubuski” 2017, t. 43, cz. 1, s. 222. 
o powodzeniu całości. Szkole, która pracuje w zmiennym otoczeniu, potrzebny jest przywódca, który komunikuje, że wierzy w możliwości nauczycieli, czerpie radość z tego, że ludzie się rozwijają, nie widząc w tym zagrożenia dla swojej pozycji”"22. Rolą dyrektora w procesie wprowadzania zmian w szkole jest dążenie przede wszystkim do tego, by „przydzielane nauczycielom zadania pozwoliły im na przejście od świadomej niekompetencji do świadomej kompetencji, co wymaga w szkole zaufania - zaufania pozwalającego także uczyć się na błędach i dającego podwaliny do budowania nowych wzorców zachowan’”23. „W kierowaniu szkołą, u podstaw którego tkwi zwrócenie się w stronę myślenia strategicznego, dominuje zatem przywództwo edukacyjne, które prowadzi zarówno do osiągania krótkoterminowych celów, jak i do budowania zdolności i możliwości osiągania celów długoterminowych, które wynikają z przyjętej przez przywódcę i nauczycieli przemyślanej filozofii edukacji i sprzymierzania się z potencjalną rzeczywistością, antycypowania zdarzeń, trendów”24.

G. Mazurkiewicz ${ }^{25}$ zauważa, że jedynym możliwym podejściem do przywództwa we współczesnej szkole nastawionej na konstruowanie wiedzy jest projektowanie tego procesu tak, aby umożliwiał partycypację w nim jak największej liczbie członków danej uczącej się społeczności, podkreślając, że „wartością autoteliczną przywództwa edukacyjnego jest szeroka partycypacja pracowników w procesie budowania wizji oraz podejmowania decyzji i wprowadzania ich w życie, a przez to branie odpowiedzialności za ich rezultaty"26.

Według J. Michalak-Madalińskiej ${ }^{27}$ przywództwo edukacyjne jest procesem dziejącym się w czasie, w którym udział biorą zarówno nauczyciele, uczniowie, rodzice, jak i osoby przewodzące szkole. Autorka ta podkreśla, że przywództwo edukacyjne dyrektora szkoły charakteryzuje się tym, że ludzie są „prowadzeni” w stronę współpracy tak, aby mogli wspólnie działać w celu osiągania pożądanych celów i realizacji określonych zadań. Autorka ta zauważa także, że przywództwo edukacyjne odnosi się

22 B. Tołwińska, Kierowanie szkoła: rola dyrektora - partycypacja nauczycieli, [w:] S.M. Kwiatkowski, J. Madalińska-Michalak, I. Nowosad (red.), Przywództwo edukacyjne w szkole i jej otoczeniu, Difin, Warszawa 2011, s. 108.

${ }^{23}$ J. Madalińska-Michalak, Przywództwo dyrektora szkoły..., dz. cyt., s. 224.

24 J. Madalińska-Michalak, Przywództwo i jego wyzwania w warunkach kultury neoliberalnej, [w:] S.M. Kwiatkowski, J. Madalińska-Michalak, I. Nowosad (red.), Przywództwo edukacyjne w szkole i jej otoczeniu, Difin, Warszawa 2011, s. 52.

${ }^{25}$ G. Mazurkiewicz, Przywództwo edukacyjne - nowy paradygmat zarządzania w oświacie, [w:] S.M. Kwiatkowski, J. Madalińska-Michalak, Przywództwo edukacyjne $w$ teorii i praktyce, Fundacja Rozwoju Systemu Edukacji, Warszawa 2010, s. 127.

26 G. Mazurkiewicz, Przywództwo edukacyjne. Odpowiedzialne zarządzanie edukacją wobec wyzwań współczesności, Wydawnictwo Uniwersytetu Jagiellońskiego, Kraków 2011, cyt. za: G. Mazurkiewicz, Przywództwo dla uczenia się. Jak wyjść poza schemat, [w:] S.M. Kwiatkowski, J. Madalińska-Michalak, I. Nowosad (red.), Przywództwo edukacyjne w szkole i jej otoczeniu, Difin, Warszawa 2011, s. 26-27.

27 J. Madalińska-Michalak, Skuteczne przywództwo w szkołach na obszarach zaniedbanych społecznie. Studium porównawcze, Wydawnictwo Uniwersytetu Łódzkiego, Łódź 2012, s. 140. 
do relacji, w której jej uczestnicy zarówno są tymi, którzy ją „kształtują”, „kształtują się”, jak i są „kształtowani” przez siebie nawzajem ${ }^{28}$.

W rozumieniu J. Madalińskiej-Michalak ${ }^{29}$ inicjowanie i wdrażanie zmian w szkole wymaga szczególnych kompetencji przywódczych ze strony dyrektora szkoły, u podstaw których leży między innymi specjalistyczna wiedza oraz umiejętności i kompetencje społeczne w zakresie: planowania i wprowadzania zmian; rozumienia uwarunkowań środowiskowych, ekonomicznych i prawnych funkcjonowania oświaty i przywództwa edukacyjnego; prowadzenia badań edukacyjnych i implementacji ich wyników w kreatywnych działaniach przywódcy; dostrzegania i formułowania dylematów etycznych pojawiających się w polu działania lidera oraz poszukiwania optymalnych rozwiązań; budowania zespołu i kierowania zespołem; kształtowania atmosfery współpracy i kultury organizacyjnej; wywierania wpływu i budowania relacji; motywowania innych do współpracy w dążeniu do osiągania ważnych celów edukacyjnych; porozumiewania się w różnych środowiskach społecznych i zawodowych oraz współpracy ze środowiskiem lokalnym oraz ponadlokalnym.

\section{Teoria konstruktywizmu jako znaczący nurt w nowoczesnej szkole}

Konstruktywistyczny model edukacji to fundament realizacji idei edukacji poprzez proces uczenia się polegający na konstruowaniu własnych struktur wiedzy przez myślący podmiot w miejsce przyswajania w nurcie tradycyjnym gotowych treści czy szablonów. „Konstruktywizm jest określeniem myślenia o edukacji opartej na twórczej, poznawczej aktywności ucznia, na wychodzeniu od jego wiedzy i przekonań. Nurt ten bazuje na dwóch podstawowych założeniach epistemologicznych: wiedza jest aktywnie konstruowana przez podmiot poznający oraz dochodzenie do wiedzy jest procesem adaptacyjnym, w którym następuje stopniowa umysłowa organizacja badanego i doświadczanego świata" ${ }^{30}$.

Konstruktywistyczne rozumienie procesu uczenia się uruchamia odmienną od dotychczasowej perspektywę oglądu relacji nauczyciel-uczeń, polegającą na tym, że to uczeń poszukuje znaczeń i buduje własne rozumienie, natomiast nauczyciel pełni rolę inicjatora i przewodnika, który wspiera ucznia w poznawczym przetwarzaniu informacji i konstruowaniu osobistych struktur wiedzy. Punktem wyjścia dla uczenia się staje się więc aktywność uczniów, którzy podejmują próby radzenia sobie z no-

${ }^{28}$ J. Madalińska-Michalak, Dyrektor szkoly liderem - inspiracje i perspektywy, Wolters Kluwer, Warszawa 2015.

${ }^{29}$ J. Madalińska-Michalak, Wspólnoty praktyków a granice uczenia się nauczycieli w szkole. Rola dyrektora szkoły, [w:] A. Minczanowska, A. Szafrańska-Gajdzica, M.J. Szymański (red.), Szkoła. Wspólnota dążeń?, Wydawnictwo Adam Marszałek, Toruń 2016.

${ }^{30}$ M. Spitzer, Jak uczy się mózg, PWN, Warszawa 2012, s. 54. 
wymi sytuacjami poprzez włączenie osobistych strategii rozwiązywania problemów ${ }^{31}$. Każdy uczeń jako indywidualna jednostka posiada określone potrzeby edukacyjne, dysponuje własnym, osobistym bagażem doświadczeń oraz prezentuje odrębny sposób myślenia. „Odkrycie i zrozumienie własnego stylu uczenia się, poznanie swoich mocnych i słabych stron stwarza szanse doświadczania siebie jako inicjatora, realizatora i kontrolera w procesie uczenia się, uruchamia wyższe funkcje mentalne, pozwala refleksyjnie odnieść się do własnej aktywności oraz daje poczucie odpowiedzialności za własny rozwój" 32 . Podmiot uczący się staje się więc w takim toku procesu edukacyjnego osobą odpowiedzialną za samodzielne wyznaczanie celów, zarządzanie swoimi działaniami oraz monitorowanie postępów. „Uczeń, który formułuje pytania poznawcze, a później poszukuje na nie odpowiedzi, przygotowuje się do przejmowania odpowiedzialności za własne uczenie się. Poprzez stwarzanie uczniom sytuacji podejmowania odpowiedzialności za własne uczenie się, tj. nieregularne, nieszablonowe sprawdzanie zadań domowych, pojawia się szansa wdrażania uczniów do przejmowania kontroli nad własnym uczeniem się. Odczuwane przez ucznia miejsce kontroli uczenia się będzie związane także z nim samym, a nie wyłącznie z nauczycielem"33.

Według W. Walata ${ }^{34}$ przedstawiciele tej koncepcji konstruktywistycznej kierują się następującymi zasadami w obszarze edukacji:

- uczenie się jest poszukiwaniem znaczenia, dlatego zaczyna się od znanych uczniom zagadnień i to właśnie wtedy starają się skonstruować ich znaczenie;

- znaczenie wymaga zrozumienia zarówno całości, jak i części - proces uczenia się musi ogniskować się na pojęciach podstawowych, a nie na izolowanych faktach;

- nauczyciel powinien zrozumieć „modele mentalne”, którymi posługuje się uczeń (uczniowie), aby wspomagać ich w poznawaniu świata zgodnie z modelami, którymi się posługują;

- cele nauczania koncentrują się na konstruowaniu własnych znaczeń (indywidualnych - subiektywnych), a nie uczeniu się na pamięć.

Podobnie założenia konstruktywizmu jako teorii wiedzy i poznawania interpretuje S. Dylak ${ }^{35}$, systematyzując je w następujący sposób:

- wiedza nie jest „poza nami” i nie czeka, aby być odkrytą, rzeczywistość nie istnieje oddzielnie od obserwatora, jest to jedność, to obserwator tworzy znaczenie tego, co widzi, świat, w którym żyje;

${ }^{31}$ J. Nowak, dz. cyt., s. 67.

32 Tamże, s. 67.

${ }^{33}$ G. Chorab, Nauczyciel w paradygmacie konstruktywistycznym, „Szkoła. Zawód. Praca” 2017, nr 13, s. 48 .

${ }^{34} \mathrm{~W}$. Walat, Poszukiwanie nowego modelu edukacji w oparciu o idee kognitywizmu i konstruktywizmu, „Edukacja - Technika - Informatyka” 2010, t. 1(2), s. 34.

35 S. Dylak, Konstruktywizm jako obiecująca perspektywa kształcenia nauczycieli, „Edukacja przyrodnicza w szkole podstawowej” 2000, zeszyt specjalny, s. 15-33. 
- opierając się na współczesnej psychologii, filozofii i antropologii, teoria ta opisuje wiedzę czasowo zdeterminowaną, rozwojową, wewnętrznie konstruowaną, kulturowo i społecznie uwarunkowaną;

- wiedza jest konstrukcją zbudowaną przez podmiot poznający, ale jest ona także konstruowana społecznie;

- wiedza nie składa się wyłącznie z faktów, zasad i teorii wyprowadzanych z obserwacji zjawisk i zdarzeń, wiedza to także zdolność wykorzystywania informacji w racjonalny sposób;

- wiedza to także uczucia i interpretacje, to wreszcie nieustanna interpretacja znaczenia zdarzeń i zjawisk.

D. Klus-Stańska twierdzi, że „konstruktywizm jest złożoną funkcjonalną poznawczo-społeczną strukturą koncepcyjną, bazującą na określonym języku, uwikłaną w wartości i emocjonalno-intelektualną postawę wobec świata, siebie i swojego w tym świecie miejsca"36. Autorka podkreśla przy tym, że elementy konstruktywizmu nie są zupełnie nowatorskie, bowiem przewijały się wielokrotnie w różnych koncepcjach naukowych, co doprowadziło w ostatnich latach do zjednoczenia tych podobnie ukierunkowanych wątków poznawczych w całość opatrzoną nazwą konstruktywizm. Podstawą tego ujednolicenia jest kluczowe założenie i jednocześnie trzon teorii konstruktywistycznego modelu edukacji, zgodnie z którym „o wiedzy nie przesądza [...] świat, będący przedmiotem poznania, ale kształtujący to poznanie współczynnik humanistyczny czy interpretacja humanistyczna ${ }^{37}$.

J. Kordziński ${ }^{38}$ podkreśla, że konstruktywizm jako nurt edukacyjny zakłada przede wszystkim traktowanie ucznia jako aktywnego podmiotu, który posiadając określone zasoby w postaci przypadkowych informacji, uzupełnianych mniej lub bardziej intencjonalnie i z reguły subiektywnie, powinien w wyniku współpracy z nauczycielem zaangażować się w tworzenie autonomicznych, możliwie całościowych, spójnych i funkcjonalnych konstrukcji. Cel ten jest możliwy do osiągnięcia wtedy, kiedy organizacja procesu kształcenia umożliwi korzystanie z wiedzy zastanej uczniów i pozwoli na jej rozwijanie poprzez włączanie kolejnych elementów, tak by dokonywali oni własnych interpretacji i samodzielnie podejmowali próby nadawania znaczenia temu, czego doświadczyli.

Tak więc konstruktywistyczna teoria uczenia się kładzie szczególny nacisk na proces budowy oraz rozwijania nowych umiejętności i kompetencji, dla którego bazę stanowią przede wszystkim czynniki, takie jak aktywność i mobilizacja ucznia umożliwiające mu samodzielne budowanie rzeczywistości poprzez samodzielne konstruowanie nowej wiedzy, rozwijanie i systematyzowanie tej wiedzy oraz kształtowa-

${ }^{36}$ D. Klus-Stańska, Dydaktyka wobec chaosu pojęć i zdarzeń, Wydawnictwo Akademickie Żak, Warszawa 2010, s. 263.

37 Tamże, s. 263.

${ }^{38}$ J. Kordziński, dz. cyt., s. 17. 
nie i doskonalenie umiejętności i kompetencji. „Praca ta odbywa się w nieustannej interakcji z otoczeniem, pogłębionej o konfrontację z samym sobą" ${ }^{39}$.

Zauważyć należy również, że w konstruktywistycznym modelu edukacji zmienia się też rola nauczyciela, który powinien być jednostką niezwykle kreatywną oraz traktować proces edukacyjny jako działanie twórcze i oryginalne, wychodzące naprzeciw wychowankom oraz uwzględniające ich potrzeby, indywidualne możliwości, zainteresowania, zdolności, a także deficyty, problemy i trudności. W preferowanej współcześnie, konstruktywistycznej kulturze uczenia się uczeń staje się animatorem własnej ścieżki rozwojowej, natomiast nauczyciel pełni funkcję „trenera uczenia się”, pomaga uczniom poznawać i doskonalić strategie uczenia się oraz dopasować je do danego kontekstu i konkretnej sytuacji ${ }^{40}$.

\section{Podsumowanie}

Przed współczesną szkołą stawiane są coraz bardziej złożone wyzwania i wymagania generowane przez potrzeby otaczającej, dynamicznej rzeczywistości. Podstawowym wymogiem współczesności jest dążenie do tego, by, jak twierdzi J. Morbitzer ${ }^{41}$, instytucja szkoły stała się środowiskiem uczenia się w miejsce transmisyjnego przekazywania wiedzy i by skoncentrowała swoje wysiłki na tworzeniu warunków i sytuacji, umożliwiających poszukiwanie, tworzenie oraz przetwarzanie informacji. „Szkoła to środowisko wychowawcze, w którym dążenie do wszechstronnego rozwoju ucznia stanowi płaszczyznę działalności edukacyjnej, realizowanej przez nauczycieli, którzy nadają jej kształt, generują jej wymiary i zaopatrują ją w podstawowe wartości” ${ }^{42}$.

Powielanie tradycyjnych koncepcji nauczania w czasach niezwykle dynamicznych zmian i wobec nowych potrzeb życia jednostkowego i społecznego okazuje się bowiem w zasadzie bezużyteczne, a nawet generuje pewne bariery w procesie rozbudzania odwagi intelektualnej i krytycyzmu oraz kształtowania poczucia sprawczości i poczucia własnej wartości, które jednocześnie utrudniają otwarcie się młodego pokolenia na nowe, nieznane dotąd możliwości. „Otwarcie się na szeroko rozumiane zmiany stanowi dużą szansę na wzbogacenie indywidualności jednostki, wzrost refleksyjności, możliwości wyboru, budowania jakości życia, współpracy i integracji społecznej. Kapitał intelektualny i społeczny tworzony w praktyce edukacyjnej staje

\footnotetext{
39 Tamże, s. 18.

40 J. Nowak, dz. cyt., s. 68.

${ }^{41}$ J. Morbitzer, Szkoła w epoce płynnej nowoczesności, [w:] E. Musiał, I. Pulak (red.), Człowiek, media, edukacja, Katedra Technologii i Mediów Edukacyjnych, Uniwersytet Pedagogiczny im. KEN, Kraków 2011, s. 222-223.

42 G. Cęcelek, School as an Institution Helping the Young to Meet Their Future, "Journal of Human Dignity and Wellbeing” 2016, No. 1(1), http://johdaw.com/download/journals/johdaw 12016 web.pdf [dostęp: 2.12.2020].
} 
się jednym z najważniejszych czynników działania na rzecz zmiany"43. Zgodnie z konstruktywistyczną teorią uczenia się edukacja powinna być postrzegana jako wspomaganie ucznia w procesie wytwarzania znaczeń, które umożliwiają konstruowanie własnego rozumienia świata oraz stanowią podstawę kształtowania zachowań pozwalających na adaptację do nieustannie zmieniającej się rzeczywistości społeczno-kulturowej.

Warto podkreślić, że szkoła nie jest oczywiście w stanie zaspokoić wszystkich potrzeb uczniów, ale może stworzyć bardzo ważną przestrzeń możliwości w tym zakresie, zadbać o kreowanie inspirującego środowiska wychowawczego, które stanowić będzie fundament trenowania umiejętności współpracy, kreatywności, uczenia się i poznawania samego siebie. Uczniowie potrzebują bowiem odpowiedniego otoczenia dla podjęcia samodzielnej aktywności poznawczej, potrzebują właściwych przykładów jako wzorów dla własnego postępowania oraz dużo inspirującej przestrzeni do działania. Szkoła jako instytucja ucząca się, organizująca uczenie się uczniów i wyrównująca szanse edukacyjne wszystkich wychowanków powinna położyć nacisk przede wszystkim na budowanie kreatywnego, wartościowego środowiska wychowawczego przygotowującego wychowanków do świadomego konstruowania swojej przyszłości, powinna przyjąć koncepcję kształcenia gotowości do zetknięcia się z przyszłością oraz aktywnego jej planowania i modelowania.

Widoczne jest wyraźnie, że w teorii edukacyjnej nastąpiło już przesunięcie z paradygmatu nauczania do paradygmatu uczenia się, z przekazu i uczenia się „po śladzie” do uczenia się innowacyjnego, partycypacji i zaangażowania, od uczenia się w pojedynkę do uczenia się wspólnotowego, od instrukcyjnego kierowania przez nauczyciela aktywnością dziecka do negocjacji i delegowania odpowiedzialności za uczenie się do dzieci; te podejścia teoretyczne czekają jednak na zakorzenienie się w nauczycielskim myśleniu i wprowadzenie do praktyki edukacyjnej ${ }^{44}$. Szczególny nacisk należy więc w aktualnej sytuacji położyć na rzeczywiste przeniesienie teoretycznych założeń koncepcji szkoły opartej na konstruktywistycznym modelu edukacji do działania praktycznego.

\section{Bibliografia}

Bałachowicz J., Szkoła jako przestrzeń budowania przyszłości, [w:] J. Bałachowicz, A. Korwin-Szymanowska, E. Lewandowska, A. Witkowska-Tomaszewska,

${ }^{43}$ G. Cęcelek, Kompetencje..., dz. cyt., s. 180.

${ }^{44}$ J. Bałachowicz, Szkoła jako przestrzeń budowania przyszłości, [w:] J. Bałachowicz, A. Korwin-Szymanowska, E. Lewandowska, A. Witkowska-Tomaszewska, Zrozumieć uczenie się. Zmienić wczesna edukacje, Wydawnictwo Akademii Pedagogiki Specjalnej, Warszawa 2017, s. 92. 
Zrozumieć uczenie się. Zmienić wczesna edukację, Wydawnictwo Akademii Pedagogiki Specjalnej, Warszawa 2017.

Bauman Z., 44 listy ze świata płynnej nowoczesności, Wydawnictwo Literackie, Warszawa 2011.

Borawska-Kalbarczyk K., Konstruktywistyczna teoria kształcenia w praktyce edukacyjnej - wybrane aspekty, „Kultura i Edukacja” 2012, nr 1(87).

Cęcelek G., Kompetencje społeczne nauczyciela szkoły uczenia się i wyrównywania szans edukacyjnych, Wydawnictwo Adam Marszałek, Torun 2020.

Cęcelek G., School as an Institution Helping the Young to Meet Their Future, "Journal of Human Dignity and Wellbeing” 2016, No. 1(1), http://johdaw.com/download/journals/johdaw 12016 web.pdf [dostęp: 2.12.2020].

Chorab G., Nauczyciel w paradygmacie konstruktywistycznym, „Szkoła. Zawód. Praca” 2017, nr 13.

Dylak S., Konstruktywizm jako obiecująca perspektywa kształcenia nauczycieli, „Edukacja przyrodnicza w szkole podstawowej” 2000, zeszyt specjalny.

Federowicz M., Sitek M., Społeczeństwo w drodze do wiedzy. Raport o stanie edukacji 2010, Instytut Badań Edukacyjnych, Warszawa 2011.

Hammerschmidt U., Ucząca się szkoła? Uczacy się nauczyciele! Próba refleksji krytycznej i punkt wyjścia do rekonstrukcji, [w:] G. Mazurkiewicz, Teoria ewolucji. Od rozwoju jednostek do rozwoju wspólnoty, Wydawnictwo Uniwersytetu Jagiellońskiego, Kraków 2015.

Kawka Z., Edukacja szansa na integrację społeczną, [w:] M. Kozłowski (red.), Edukacja jako szansa na integrację społeczna, Wydawnictwo Państwowej Wyższej Szkoły Zawodowej w Skierniewicach, Skierniewice 2010.

Klus-Stańska D., Dydaktyka wobec chaosu pojęć i zdarzeń, Wydawnictwo Akademickie Żak, Warszawa 2010.

Kordziński J., Szkoła uczenia się, Wolters Kluwer, Warszawa 2018.

Madalińska-Michalak J., Dyrektor szkoły liderem - inspiracje i perspektywy, Wolters Kluwer, Warszawa 2015.

Madalińska-Michalak J., Przywództwo dyrektora szkoły a zmiana i uczenie się nauczycieli we wspólnotach praktyków, „Rocznik Lubuski” 2017, t. 43, cz. 1.

Madalińska-Michalak J., Przywództwo i jego wyzwania $w$ warunkach kultury neoliberalnej, [w:] S.M. Kwiatkowski, J. Madalińska-Michalak, I. Nowosad (red.), Przywództwo edukacyjne w szkole i jej otoczeniu, Difin, Warszawa 2011.

Madalińska-Michalak J., Skuteczne przywództwo w szkołach na obszarach zaniedbanych społecznie. Studium porównawcze, Wydawnictwo Uniwersytetu Łódzkiego, Łódź 2012.

Madalińska-Michalak J., Wspólnoty praktyków a granice uczenia się nauczycieli w szkole. Rola dyrektora szkoły, [w:] A. Minczanowska, A. Szafrańska-Gajdzica, M.J. Szymański (red.), Szkoła. Wspólnota dążeń?, Wydawnictwo Adam Marszałek, Toruń 2016. 
Mazurkiewicz G., Przywództwo dla uczenia się. Jak wyjść poza schemat, [w:] S.M. Kwiatkowski, J. Madalińska-Michalak, I. Nowosad (red.), Przywództwo edukacyjne w szkole i jej otoczeniu, Difin, Warszawa 2011.

Mazurkiewicz G., Przywództwo edukacyjne - nowy paradygmat zarządzania w oświacie, [w:] S. Kwiatkowski M.J. Madalińska-Michalak, Przywództwo edukacyjne w teorii i praktyce, Fundacja Rozwoju Systemu Edukacji, Warszawa 2010.

Mazurkiewicz G., Przywództwo edukacyjne. Odpowiedzialne zarządzanie edukacja wobec wyzwań współczesności, Wydawnictwo Uniwersytetu Jagiellońskiego, Kraków 2011.

Morbitzer J., Szkoła w epoce płynnej nowoczesności, [w:] E. Musiał, I. Pulak (red.), Człowiek, media, edukacja, Katedra Technologii i Mediów Edukacyjnych, Uniwersytet Pedagogiczny im. KEN, Kraków 2011.

Nowak J., Środowisko uczace - (nie)doceniony obszar edukacji, [w:] K. Kruszko, I. Nowakowska-Buryła (red.), Problemy edukacji wczesnoszkolnej. Perspektywa teoretyczna i rozwiązania praktyczne, Wydawnictwo UMCS, Lublin 2015.

Ochremiak A., Nierówności edukacyjne - problem nie tylko pedagogiczny, „Problemy Opiekuńczo-Wychowawcze" 2002, nr 8.

Spitzer M., Jak uczy się mózg, PWN, Warszawa 2012.

Stępień R., Aktualne tendencje rozwoju dydaktyki ogólnej i jej rola w edukacji pedagogicznej, [w:] R. Stępień (red.), Kształcenie pedagogów w szkole wyższej. Teoria i praktyka, Akademia Humanistyczna im. Aleksandra Gieysztora w Pułtusku, Pułtusk 2015.

Tołwińska B., Kierowanie szkoła: rola dyrektora - partycypacja nauczycieli, [w:] S.M. Kwiatkowski, J. Madalińska-Michalak, I. Nowosad (red.), Przywództwo edukacyjne w szkole i jej otoczeniu, Difin, Warszawa 2011.

Walat W., Poszukiwanie nowego modelu edukacji w oparciu o idee kognitywizmu i konstruktywizmu, „Edukacja - Technika - Informatyka” 2010, t. 1(2). 


\section{Learning environment as the basis for the functioning of modern school}

Abstract: The dynamics and complexity of the modern world are important challenges for educational systems that prepare young people to participate and cope with the surrounding reality and to actively co-create the future. Accelerated technological progress and global competition are factors accompanying the existence of modern man and, at the same time, important determinants of the life path aimed at obtaining the appropriate social status. Therefore, the priority is to anticipate the future and educate to changes taking place in every area of social functioning.

These needs make the traditional forms of educational message obsolete and at the same time generate the need to replace the process of adaptive education with innovative and forward-looking education, focused on the process of building and developing new competences. Therefore, an important task of a modern school is to open up to changes and to search for adequate, adapted to new needs, models of pedagogical activity. The formula of the new concept of education is the preference for the learning process carried out at school as a learning organization - based on the assumptions of the constructivist model of education, assuming the recognition of the child's own activity as the main mechanism of its developmental changes.

Keywords: school, education, teaching, learning, constructivist model of education, constructing knowledge

\section{About the Author:}

Grażyna Cęcelek - doctor of humanities in the field of pedagogy (academic degree obtained at the University of Warsaw). Author and co-editor of pedagogical monographs and over 100 scientific articles on the border of social, guardian and educational and resocialization pedagogy, as well as in the field of pre-school and early school education, pedeutology, educational, vocational and personal consulting as well as those dealing with the issues of permanent education, e-education and media pedagogy - published in Polish and foreign periodicals and scientific monographs. 